\title{
A re-examination of the type material of Entomoneis paludosa (W SмIтн) REIMER and its morphology and distribution in African waters
}

\author{
Tatenda Dalu ${ }^{1 *}$, Jonathan C. TAYloR ${ }^{2,3,4}$, Nicole B. Richoux ${ }^{1}$ \& P. William \\ FRONEMAN $^{1}$
}

\author{
${ }^{1}$ Zoology and Entomology, Rhodes University, P O Box 94, Grahamstown 6140, South Africa; *Corresponding \\ authore-mail: dalutatenda@yahoo.co.uk \\ ${ }^{2}$ School of Biological Sciences, North-West University, P Bag X6001, Potchefstroom 2520, South Africa \\ ${ }^{3}$ South African Institute for Aquatic Biodiversity (SAIAB), P Bag 1015, Grahamstown 6140, South Africa \\ ${ }^{4}$ Botanic Garden Meise, Nieuwelaan 38, 1860 Meise, Belgium
}

\begin{abstract}
The current study aims to enhance the understanding of the distribution and morphology of the diatom Entomoneis paludosa W SмIтH 1853 in African waters. The type material of Entomoneis paludosa (W SMITH) ReIMER was examined using light and scanning electron microscopy and the morphological characters were compared with new specimens sampled from a temperate river in South Africa. The wider distribution of this taxon on the African continent is discussed, and its relationship to water quality variables.
\end{abstract}

Key words: benthic, distribution, Entomoneis paludosa, Kowie system, morphology

\section{INTRODUCTION}

There are currently 44 species and infraspecific taxa in the genus Entomoneis (family: Entomoneidaceae) in the Integrated Taxonomic Information Systems, National Center for Biotechnology Information taxonomy and World Register of Marine Species database at present, of which 16 have been flagged as currently accepted taxonomically including Entomoneis paludosa (W Smith) Reimer (Scott \& Thomas 2005). The original publication and holotype designation of Entomoneis paludosa was by W Sмгтн (1853) as Amphiprora paludosa and was later transferred to Entomoneis by Reimer in in 1975 (SALVADOR in GUIRY \& GUIRY 2014). To our knowledge, no study of William Smith's type material has since been carried out.

The diatom Entomoneis paludosa is an epipelic diatom that occurs in streams with elevated salinity, and there have been reports of this species occurring in standing waters with elevated electrolyte concentrations (BAHLS 2012). Little information is known on the present distribution and morphology of this species on the African continent, and therefore this paper aims to contribute towards the knowledge base in terms of distribution and morphology of E. paludosa, and to compare the morphological characteristics of the cells from our samples to those found in the type material. We discuss E. paludosa var. subsalina (CLEVE) KRAMMER and postulate that it may be con-specific with the nominate variety but to confirm this there will need to be further studies of Cleve's type material as well as morphological and molecular studies of discrete populations. This is unfortunately outside the scope of the present study.

\section{Materials ANd Methods}

Study area. The Kowie River is a permanently open temperate system draining a relatively small catchment area of approximately $800 \mathrm{~km}^{2}$ (HeYdoRN \& GRINDLEY 1982; Whitfield et al. 1994). The Kowie River is classified as intermediate and its source is the Cape Fold Belt Mountains. Its major tributaries are the Bloukrans, Brakrivier and Lushington (or Torrens) Rivers (Heydorn \& Grindley 1982). Epipelic diatom samples were collected along the Kowie system,

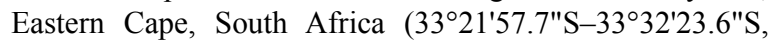
$026^{\circ} 37^{\prime} 38.0^{\prime \prime} \mathrm{E}-026^{\circ} 48^{\prime} 13.0^{\prime \prime E}$ ), from seven study sites over four periods: September 2012, December 2012, February 2013 and May 2013 (Fig. 1). Freshwater sites F1 and F2 were polluted with sewage draining from Grahamstown.

Diatom sampling and processing. The benthic habitat in the Kowie River was dominated by clay/silt (55\%) and cobbles or rocks $(45 \%)$ with decaying detritus. The submerged macrophyte Cyperus eragrostis LAMARCK covered most of the littoral zone (60\%), with Phragmites australis (CAVANILles) TRINIUS ex STEUdel covering $15 \%$ of the total littoral zone surface area in the river section while Schoenoplectus brachyceras (HochsteTter ex A RichARD) Lye (53\%) and Spartina maritima (CURTIS) Fernald (32\%) were the dominant macrophytes in the estuary (DALU et al. 2014). Epipelic diatom samples were collected in $500 \mathrm{ml}$ 
containers from the Kowie system. Samples were digested in potassium permanganate and hydrochloric acid an mounted in Pleurax (r.i. 1.73), for details see TAYLOR et al (2005). After sample preparation an aliquot was dried onto and viewed using an FEI Quanta FSEM electron milladiun housed at the laboratory for Electron Microscopy, NorthWest University. Light microscope (LM) studies were carried out using a Nikon $80 \mathrm{i}$ compound light microscope, equipped with Normarski DIC and using a $100 \times 1.45$ N.A. objective. Valve width and length of specimens were measured in micrometres $(\mu \mathrm{m})$. The density or abundance of $E$. paludosa was determined by counting the numbers present in five 10 abundances (densities) were presented as number per litre.

William Smith's diatom type material, sample collection locality Lewes, England, was obtained from the collection of the Botanic Garden Meise in Belgium. Material dried on mica was stored in small folded envelopes mounted on sheets. The envelope was marked in Smith's own hand 'near Lewes, September 1852 ', exactly matching the published description of the type locality. No E. paludosa var. subsalina were of a section of the original mica preparation made by Smith, and to prevent disturbance of the integrity of the sample the mica was left intact and the cells photographed using an Olympus BX51 light microscope and colour view camera without additional cleaning or mounting in a resin Although striae may not be observed in this manner, the shape, size and key features of cell morphology are visible. An additional very small section of mica was mounted on an under scanning electron microscope (SEM)

Physico-chemical factors sampling and analysis. conductivity, salinity, total suspended solids, sodium chloride, resistivity and water transparency were measured using portable probes (CyberScan Series 600, Eutech Instruments, Singapore). Flow velocity was measured using a portable flow meter (Flo-mate Model 2000, Marsh $500 \mathrm{ml}$ polyethylene bottles for further laboratory analysis of phosphate, nitrate and ammonia using standard methods for examining water and wastewater (EATON et al. 2005).

Data analysis. We analysed locality and demographic data from the earliest available records to the present for Entomoneis paludosa in Africa. We undertook systematic terms ' $E$. paludose' 'A mphipry publication year, using the "Amphiprora paludosa', 'Amphicampa paludosa' 'Amphiprora paludosa var. africana' 'Amphiprora venusta' Amphiprora paludosa var. pokornyana' and 'Amphitropis paludosa' in the academic search engines Scopus, Google Scholar and Web of Science. We reviewed reference lists of papers mentioning the species and searched peer reviewed African and international aquatic journals including African Journal of Aquatic Science, African Journal of Diatomologica, Botanica Marina, South African Journal of Science, Diatom Research, Journal of Applied Phycology, Hydrobiologia, Nova Hedwigia, Revista de Biologia Transactions of the Royal Society of South Africa, West
African Journal of Ecology, Water SA and Zoologica le, expedition reports, checklists and project reports from National Museums.

Entomoneis paludosa density values were $\log (\mathrm{x}+1$ determine whether to use linear or unimodal methods for the analysis, detrended canonical correspondence analysis (DCA) was employed. The gradient lengths were examined and since the longest gradients were between 3 and 4, unimodal model RDA was selected (Lepš \& Šmllauer 2003). RDA was performed on the E. paludosa datasets to examine the relationships between $E$. paludosa taxa and permutations at $\mathrm{p}<0.05$ signifecence level in Canoco versio 4.5 software (TER BRAAK 2002).

Multiple regression analysis was carried out using $\log (x+1)$ transformed data to evaluate the relationships that existed between the physico-chemical factors and E. paludos species abundances. A non-parametric Kruskal-Wallis tes was used to test for differences in physico-chemical factor among sites and time periods after the data was found to
violate several ANOVA assumptions tested using ShapiroWilk test SPSS version 16.0 was used for statistical analysis (Spss INc. 2007).

\section{Results}

Entomoneis paludosa potential distributio

To determine the distribution of this taxon in Africa, we found 36 locality records, $29(81 \%)$ from published sources and $7(19 \%)$ from National Museum record databases. Eniomoneis paludosa was mostly identified from sites near the coastline (Table 1). Most of the records were from southern Africa $18(50 \%)$, the leas from east Africa $2(8 \%)$ and one whose exact locality could not be identified in the records (Table 1).

\section{Morphological characteristics}

Phylum: Ochrophyta

Class: Bacillariophycea

Order: Surirellales

Family: Entomoneidacea

Genus: Entomoneis

Entomoneis paludosa (W SMITH) REIMER

Basionym: Amphiprora paludosa W SMIтH

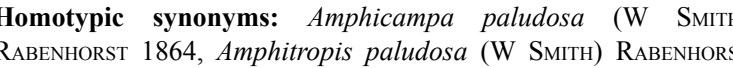
1868

SмIтн's (1853) description was based on observation of cells with lengths between 40.6 and $106.7 \mu \mathrm{m}$, an 23.6 striae in $10 \mu \mathrm{m}$. Our examination of the type material showed a greater range in striae values from 22-26 in $10 \mu \mathrm{m}$. Light microscope images from the type mica are presented in Figs 2-8 and SEM images in Figs 9-20. Figs 2 to 8 show a rather high variability in valve shape, especially with respect to the junction between the keel and the surface of the valve. When

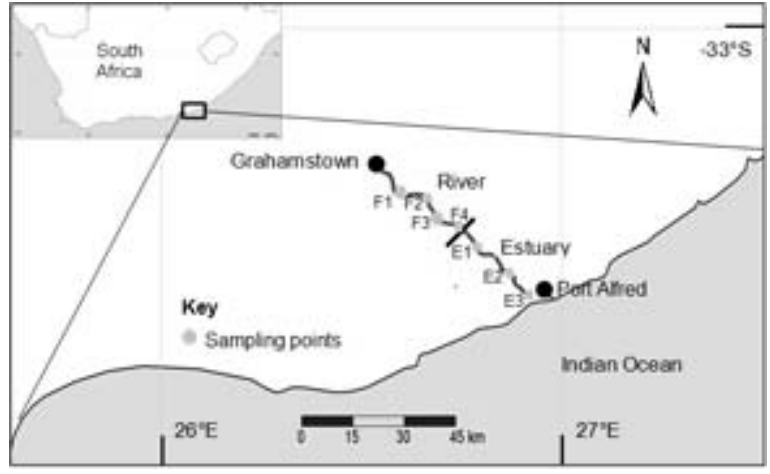
Fig. 1. Location of the sampling points on the Kowie system, Eastern
Cape (South Africa).

viewed with SEM, a number of key features become visible. Costae extend from the valve mantle to the raphe canal and separate striae are composed of single rows of areolae (Fig. 13). These areolae are occluded on the outside by hymenes (Fig. 13) and are open on the inside (Fig. 14). The girdle bands are perforated by large elongate areolae occluded by cribra (Fig. 15). The raphe is housed in a tubular canal and the distal end are slightly deflected (Fig. 16), the central endings are widened and drop-shaped (Figs 17 and 18) and may or may not be sunken in between silica ridges (Figs 17 and 18). The raphe is housed in a tubular canal which is perforated by small areolae occluded on the outside and open on the inside (Figs 19 and 20).

Scanning electron and light microscope micrographs of a single population of E. paludosa from the Kowie River system, along with data derived from СноцNоку (1966a, b), GifFEN (1970) and BAHLS (2012), were used to facilitate the elucidation of the morphology of $E$. paludosa. The length range of E. paludosa in samples from the Kowie River was $28.5-91.5 \mu \mathrm{m}$, with a valve width range of 7.8-9.3 $\mu \mathrm{m}$ excluding the keels (Figs 21 to 35$)$. The junction line which lies between the valve and keel contains a single bulge that is smoothly rounded and flattened in large specimens (Fig. 35), with that of smaller specimens being more angular (Figs 2 and 24). In valve view (Figs 32 and 39), valves at the alvar plane are linear-elliptic to linear lanceolate wit slightly concave and apiculate apices. In girdle view (complete frustules), diagonally opposing lobes lie at eproximately the same level of focus, with the lobes lattened and rounded in large and small specimens, respectively. The striae, $21-26$ in $10 \mu \mathrm{m}$, on the valve ace continue onto the keel (Fig. 43), with the areolae on the valve face being very fine and numbering $18-25$ in $10 \mu \mathrm{m}$ within a striae. The keel is strongly marked of from the valve by a basal line that is made conspicuous by striae of the keel structure. The frustules usually come to rest in girdle view, dominated by two highly arched bilobate keels, one on each valve. Areolae on the keel are much more prominent and number 22-40 in $10 \mu \mathrm{m}$ within a stria. The lobes are not all in focus due to fact hat the keels are slightly torsioned. Severa form a crossing, sigmoidal pattern (Figs 21 to 27).

Physico-chemical variation and diatom ecology The physico-chemical conditions in which the species was found are highlighted in Table 2. Conductivity, total dissolved solids (TDS), salinity, ammonia an water depth increased downstream while phospha decreased from upstream to downstream. Nitrate, temperature and $\mathrm{pH}$ generally fluctuated along the riverestuary continuum (Table 2). Significant differences $(p<0.05)$ were observed in IDS, salinity, resistivity, water depth, ammonia, conductivity and $\mathrm{pH}$ among the study sites while monthly significant differences ( $p$ 0.05 ) were observed in temperature and water velocity. Using multiple regression, we found that E. paludosa abundance was significantly negatively correlated $(\mathrm{p}=$ $0.027, \mathrm{R}=-0.43$ ) with resistivity while significantly positively correlated $(\mathrm{p}=0.007, \mathrm{R}=0.51)$ with $\mathrm{pH}$ (Figure 48). All other physico-chemical factors were not significantly correlated $(\mathrm{p}>0.05)$ with E. paludosa abundances.

No E. paludosa specimens were recorded in the sites F1 and F2 (September) and F1 (February). The highes abundances (mean of $1206 \mathrm{I}^{-1}$ ) were recorded in May. The estuary sites (mean $6561^{-1}$ ) generally had a hig numbers of $E$. paludosa compared to the river sites (mean $374 ~^{1^{-1}}$ ). After the October-November floods, there was a slight increase in the population abundance at each site.

Two physico-chemical variables (nitrates and salinity) were important in structuring E. paludosa taxa sample/sites (Fig. 49). The first and second axes of a explained $72.1 \%$ of the E. paludosa taxa sample variation. The sum of the first and second axis canonical eigenvalues was 0.72 . The polluted freshwater sites $F 1$ and F2 were associated with nitrate while estuary site E2 and E3 were associated with salinity (Fig. 49).

\section{Discussion}

Taxonomic consideration

In this paper we consider, based on our observation of type and other material, E. paludosa var. subsalin (Cleve) Krammer as a possible synonym of $E$. paludosa var. paludosa (W SMITH) ReIMER. Cleve based his original description of the variety on his observations of cells with 23 striae in $10 \mu \mathrm{m}$. Later, HUSTEDT (1930) stated that the differences between the nominate variety and $E$. paludosa var. subsalin were found in the greater number of striae and in the angle of the junction of the valve face and keel. 


\begin{tabular}{|c|c|c|}
\hline Year & Locality name & Source \\
\hline \multirow[t]{2}{*}{1930} & Unknown & Cleve-Euler \& Tell (1930) \\
\hline & EAST AFRICA & \\
\hline 1898 & Congo & LEUdUGER-ForTMOREL (1898) \\
\hline \multirow[t]{2}{*}{1986} & East Africa & GASSE (1986) \\
\hline & NORTH AFRICA & \\
\hline 1913 & Mediterranean Sea & De Toni \& Forti (1913) \\
\hline 1954 & Sidi Bou Rhaba; Dayèt er Rousini (Morocco) & GAYRAL (1954) \\
\hline 1954 & Lake Mariut (Egypt) & Јов (1954) \\
\hline \multirow[t]{2}{*}{1980} & Alexandria Harbour (Egypt) & Haeimetal (1980) \\
\hline & SOUTHERN AFRICA & \\
\hline 1947 & Goedgedacht, Zoutpansberg, Namaqualand (South Africa) - Fossil & Kent \& Rodgers (1947) \\
\hline 1960 & Mtubatuba-Mtunzini (South Africa) & СHOLNoKy (1960) \\
\hline 1963 & Eastern Cape littoral (South Africa) & GIFFen (1963) \\
\hline 1960 & Gulu River and the Yarra Stream (South Africa) & GIFFEN (1963) \\
\hline 1960 & Swartskops River, Berg River, Piketberg (South Africa) & СHoLnoKy (1960) \\
\hline 1962 & Malmesbury, Cape Town (South Africa) & Сноцпоку (1962) \\
\hline 1963 & Indian Ocean (South Africa) & Wood (1965) \\
\hline 1966 & Welkom, Freestate (South Africa) & СноLNоку (1966c) \\
\hline 1966 & Botswana & СноLnоку (1966b) \\
\hline 1966 & Nambia & Сноцпоку (1966а) \\
\hline 1968 & Santa Lucia Estuary (South Africa) & СHOLNOKY (1968) \\
\hline 1966 & Indian Ocean (South Africa) & TAYLOR (1966) \\
\hline 1970 & Kowie system (South Africa) & GIFFEN (1970) \\
\hline 1970 & Mozambique & SOURNIA (1970) \\
\hline 1975 & Swartskops Estuary (South Africa) & MASSON \& MARIAS (1975) \\
\hline 1982 & Seychelles and Mauritius & Cotze \& Ricard (1982) \\
\hline 1983 & Sundays and Great Fish Rivers (South Africa) & ARChiBALD (1983) \\
\hline $\begin{array}{l}2012- \\
2013\end{array}$ & Kowie River (South Africa) & present study \\
\hline \multirow[t]{2}{*}{2014} & Mdloti River, near coastline north of Umhlanga (South Africa) & Own samples (J.C. Taylor) \\
\hline & WEST AFRICA & \\
\hline 1898 & Sierra Leone, Cameroon & Leuduger-Fortmorel (1898) \\
\hline 1913 & Tripoli (Sierra Leone) & De Toni \& Forti (1913) \\
\hline 1956 & Dakar (Senegal) & SILVA (1956) \\
\hline
\end{tabular}

\begin{tabular}{lll}
\hline 1958 & Sierra Leone & Woodhead and Tweed (1960) \\
1960 & Senegal, Ivory Coast & Woodhead and Tweed (1958) \\
1984 & Wadides Sbeitlaflussen (Tunisia) & Wacorik (1984) \\
1986 & Gambia & Foged (1986) \\
1987 & Niger & Gasse (1987) \\
\hline
\end{tabular}

Table 2. Mean physico-chemical factors and E. paludosa abundances recorded along Kowie system in September 2012 to May 2013 [(TDS) Table 2. Mean physico-chemical factors and E. paludosa abundances recorded along Kowie syster.
total dissolved solids, (Rest) resistivity, (Temp) temperature, (Amm) ammonia, (Phos) phosphate].

\begin{tabular}{|c|c|c|c|c|c|c|c|}
\hline \multirow[t]{2}{*}{ Parameter } & \multicolumn{7}{|c|}{ Sites } \\
\hline & F1 & F2 & F3 & F4 & E1 & E2 & E3 \\
\hline TDS (ppt) & $1.1 \pm 0.7$ & $1.2 \pm 0.6$ & $1.4 \pm 0.3$ & $2.7 \pm 2.9$ & $2.7 \pm 0.9$ & $4.7 \pm 2.9$ & $19 \pm 4.4$ \\
\hline Cond $\left(\mu \mathrm{S} . \mathrm{cm}^{-1}\right)$ & $0.9 \pm 1$ & $1 \pm 0.7$ & $2.4 \pm 0.8$ & $2.6 \pm 0.4$ & $5.2 \pm 1.6$ & $9 \pm 4.3$ & $34 \pm 4.4$ \\
\hline Salinity (ppt) & $0.8 \pm 0.5$ & $0.9 \pm 0.4$ & $1 \pm 0.2$ & $1.1 \pm 0.1$ & $2.1 \pm 0.8$ & $3.7 \pm 2.5$ & $17.2 \pm 4.7$ \\
\hline $\mathrm{pH}$ & $8 \pm 0.3$ & $8.2 \pm 0.8$ & $7.4 \pm 0.7$ & $7.1 \pm 0.2$ & $7.6 \pm 0.7$ & $7.6 \pm 0.6$ & $7.7 \pm 0.4$ \\
\hline Temp $\left({ }^{\circ} \mathrm{C}\right)$ & $13.9 \pm 3.7$ & $14.9 \pm 4.9$ & $15.3 \pm 4.7$ & $15.9 \pm 4.7$ & $16.5 \pm 6.6$ & $16.6 \pm 5.9$ & $16.3 \pm 4.7$ \\
\hline Depth (m) & $0.5 \pm 0.1$ & $1 . \pm 0.1$ & $0.8 \pm 0.2$ & $0.5 \pm 0.2$ & $2 \pm 0.5$ & $2.8 \pm 0.5$ & $4.3 \pm 0.8$ \\
\hline Velocity $\left(\mathrm{m} \cdot \mathrm{s}^{-1}\right)$ & $0.1 \pm 0.1$ & $0.3 \pm 0.3$ & $0.3 \pm 0.3$ & $0.3 \pm 0.2$ & $0.2 \pm 0.1$ & $0.2 \pm 0.1$ & $0.1 \pm 0.2$ \\
\hline $\operatorname{Amm}\left(\mathrm{mg} \cdot 1^{-1}\right)$ & $0.1 \pm 0.1$ & $0.1 \pm 0.1$ & $0.2 \pm 0.2$ & $0.1 \pm 0.1$ & $0.3 \pm 0.2$ & $0.3 \pm 0.4$ & $0.5 \pm 0.3$ \\
\hline Phos (mg..$\left.^{-1}\right)$ & $0.8 \pm 1.3$ & $0.5 \pm 0.3$ & $2 \pm 4.5$ & $0.5 \pm 0.7$ & $0.2 \pm 0.3$ & $0.2 \pm 0.1$ & $1.8 \pm 2.9$ \\
\hline Nitrate $\left(\mathrm{mg} \cdot .^{-1}\right)$ & $1.3 \pm 2.1$ & $13.8 \pm 18.7$ & $1.5 \pm 2.1$ & $0.9 \pm 2.3$ & $1.9 \pm 4$ & $8.1 \pm 10.3$ & $2 \pm 3.4$ \\
\hline Abund (no. $\left.\mathrm{l}^{-1}\right)$ & $75.5 \pm 75.7$ & $581.3 \pm 429$ & $2.8 \pm 449.2$ & $4.3 \pm 543.5$ & $6.5 \pm 536.8$ & $2.8 \pm 534.9$ & $16.3 \pm 89.2$ \\
\hline
\end{tabular}

Сноцnокy (1966c) later questioned the validity of striae densities and shapes of the junction we observed this variety, but as with ARCHIBALD (1983) he did not in the type material (22-26 striae in $10 \mu \mathrm{m}$ ). For these find enough inter

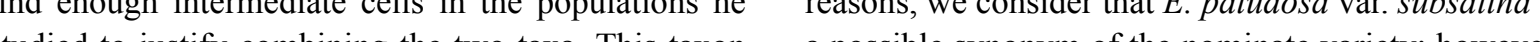
is often sporadic in its occurrence, making it difficult a before this can be confirmed an examination, however, to docum the full range of me, nolical disparity type material would need to be undertaken as well within a population. In the present study we found as morphological and molecular studies of discrete

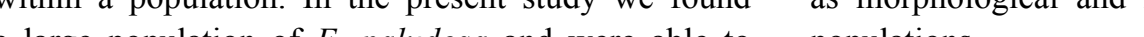
a lange population of E. paludosa and were able to typically be thought to belong to E. paludosa var. Entomoneis paludosa distribution

subsalina, as well as those more typically considered In the current study, we found E. paludosa in abundance as E. paludosa sensu stricto. This overlap of forms of $2.2-4.8 \%$ of the whole epipelon sample, which were was also observed in Smith's mica mounted material high relative to the findings of Ros et al. (2009) from (Figs 2-8), where the angle of the junction of the a tributary of the Segura River, south-east Spain [0valve face and the keel changed with changes in cell $1.2 \%$ (epilithon) and $0-0.2 \%$ (epipelon)]. DeL-Cruz size. Smith's original illustration showed a very sharp et al. (2006) reported moderate to high abundances almost 90 degree angle, while Cleve illustrated a single of E. paludosa at low nutrient levels in Australia bu smaller cell with a more gradually rounded less angled in the present study we observed a different scenario junction. Our population from the Kowie River had where E. paludosa densities were low at high nutrien striae counts ranging from 21-26 in $10 \mu \mathrm{m}$ and also concentrations. WECKSTRÖM \& JUGGINS (2005) found $E$. displayed a range of morphological differences in the paludosa had a maximum abundance of 1.1 individuals shape or angle of the junction of the valve face and per litre in the Gulf of Finland, which is lower than that the keel, all of which overlap with a similar range of of the Kowie system. 
Data-screening is a critical step in evidence-based status assessment, particularly for a species whose range is relatively unknown throughout the world (SenYATso et al. 2013). Sampling bias and spatial scale issues resulting from uneven spatio-temporal sampling effort within and across countries might otherwise have compromised the analysis of occurrence records collated through search strategies of the type used in this study. In this study, there were relatively more records for southern and west Africa due to the levels of extensive research and experts available plus the geopolitical accessibility. Therefore, we acknowledge that this work is greatly intensified if different incountry experts are sought to validate records or provide distribution trends of the E. paludosa species, as it would reduce the effort required to complete assessments. Such assessments remain possible only if diatom experts are available in different countries.

At present, E. paludosa has been thought to occur only in Europe (Britain, Finland, France, Romania and Spain), America (Brazil, New Brunswick and United States of America) and Australasia (New Zealand and western Australia; SALVADOR in GUIRY \& GUIRY 2014). Initial searches revealed no records in Africa because the species was previously identified using several synonyms such as Entomoneis paludosa (W. SMith) Reimer 1975, Amphicampa paludosa (W. SMITH) RABENHORST 1864, Amphiprora paludosa $\mathrm{W}$. SMITH 1853 and Amphitropis paludosa (EHRENBERG) RABENHORst 1868, which made it difficult to find any records (GuIRY 2013). All these misidentifications are ongoing, as is evident in the AlgaeBase website for the E. paludosa species.

Physico-chemical factors and E. paludosa communities

From the current study, the physico-chemical values were similar to those reported by GIFFEN (1970) for the Kowie system (South Africa). GIFFEN (1970) found that the species mainly occurred in water whose chloride concentrations varied from 0.42 to $16.67 \mu \mathrm{S} . \mathrm{cm}^{-1}$, which falls within our observed range of 0.9 to 34 $\mu \mathrm{S} . \mathrm{cm}^{-1}$. In North western Great Plains (Montana, North Dakota, South Dakota, Wyoming) where $E$ paludosa is dominant, the species occurred in water having conductivity and $\mathrm{pH}$ of $3.28 \mu \mathrm{S} . \mathrm{cm}^{-1}$ and 8.6 respectively (PATRICK \& Reimer 1975). Comparing with the Great Plains study, both conductivity and $\mathrm{pH}$ ell within the observed Kowie range, suggesting that species requires these conditions for it to grow.

The resistivity and $\mathrm{pH}$ levels were significantly correlated with E. paludosa abundances and played an important role in structuring the communities in this study. The relationship between diatoms and $\mathrm{pH}$ is strong, as $\mathrm{pH}$ exerts a direct physiological stress on diatoms and influences other water chemistry variables such as resistivity and conductivity (BERE \& TuNDIS 2011). Changes in the $\mathrm{pH}$ and resistivity levels migh have had a physiological effect on the species, thereby affecting their abundances across the study month Using RDA analysis, we observed that the E. paludos populations were associated with nitrates and salinity (Fig. 49). These findings are similar to a recent stud by DALU et al. (2014) on diatom communities showing that salinity was associated mostly with the estuary sites while nitrate were associated with mainly the polluted sites.

The observed sizes of $E$. paludosa specimens sugges that the species in South Africa is smaller compared to the species in other parts of the world (BAHLS 2012). In the Kowie River, the specimens were found in benthic samples and were highly motile and solitary. Entomoneis paludosa was found associated with Cymbella sp., Cyclotella sp., Thalassiosira sp., Diatoma sp., Fragilaria sp., Gomphonema sp., Navicula sp., Nizschia sp., Thblionella sp. and Surtirella sp. (Giffes 1970; Patrick \& Reimer 1975; Dalu et al. 2014). During the present study E. paludosa was associated with diatoms of the genera Achnanthidium sp., Cymbella sp., Cyclotella sp., Cymbella sp., Fallacia sp., Fragilaria sp., Gomphonema sp., Navicula sp., Nitzschia sp., Staurophora sp., Pleurosigma sp. and Surirella sp. similar to studies by GIFFEN (1970) and Patrick \& Reimer (1975).

ACKNowLEDGGMENTS
This work was supported by the Water Research Commission of
Sout and the Sandisa Imbewu initiative at Rhodes University. We than Bart van de Vijver who located and provided access to the Williaa Smith material at the Botanic Garden Meise. We are grateful to the Units for access to equipment, and Lenin D Chari, Sydney Moyo and Likho Sikutshwa for assistance with the field work. Jonatha C Taylor is the recipient of South African National Researc Foundation (NRF) incentive funding. Any opinions, findings and of the author(s) and therefore the NRF does not accept any liability in regard thereto.

\section{REFERENCES}

BAHLS, L. (2012): Entomoneis paludosa. - In Diatoms of the United States. http://westerndiatoms.colorado.edw/ taxa/species. Retrieved 31 January 2013.

BERE, T. \& TUNDIII, J.G. (2011): Diatom-based water quality assessment in streams influence by urban pollution S̃oco Carlos SP, Brazil - Brazilin J. Aqubtrates. São Carlos-SP, Brazil. - Brazhlian J. Aquat. Sci.

CHOLNoKY, B.J. (1960): Beitrage zur Kenntnis der Ökologie der Diatomeen in dem Swartkops-Bache nahe Port Elizabeth (Südost-Kaapland). - Hydrobiologia 16: 229-287.

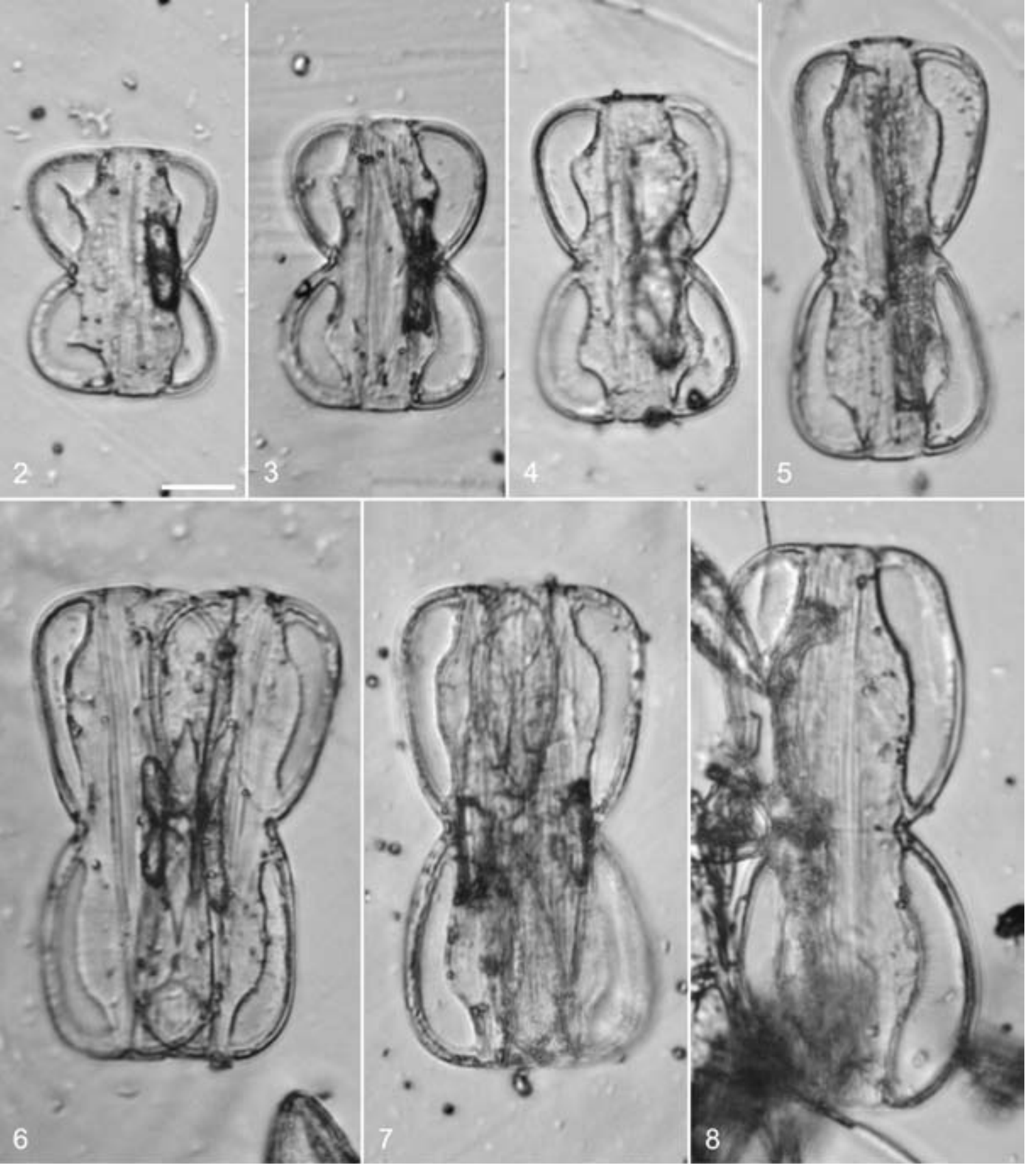

Figs 2-8. LM showing material on Smith's original mica preparation, taken from a packet marked 'Near Lewes, September 1953 in his own
hand. Image series demonstrates changes in the shape of the junction between the keel and the valve face as overall cell size changes. Material is uncleaned and mounted in air. Scale bar 10 um. 


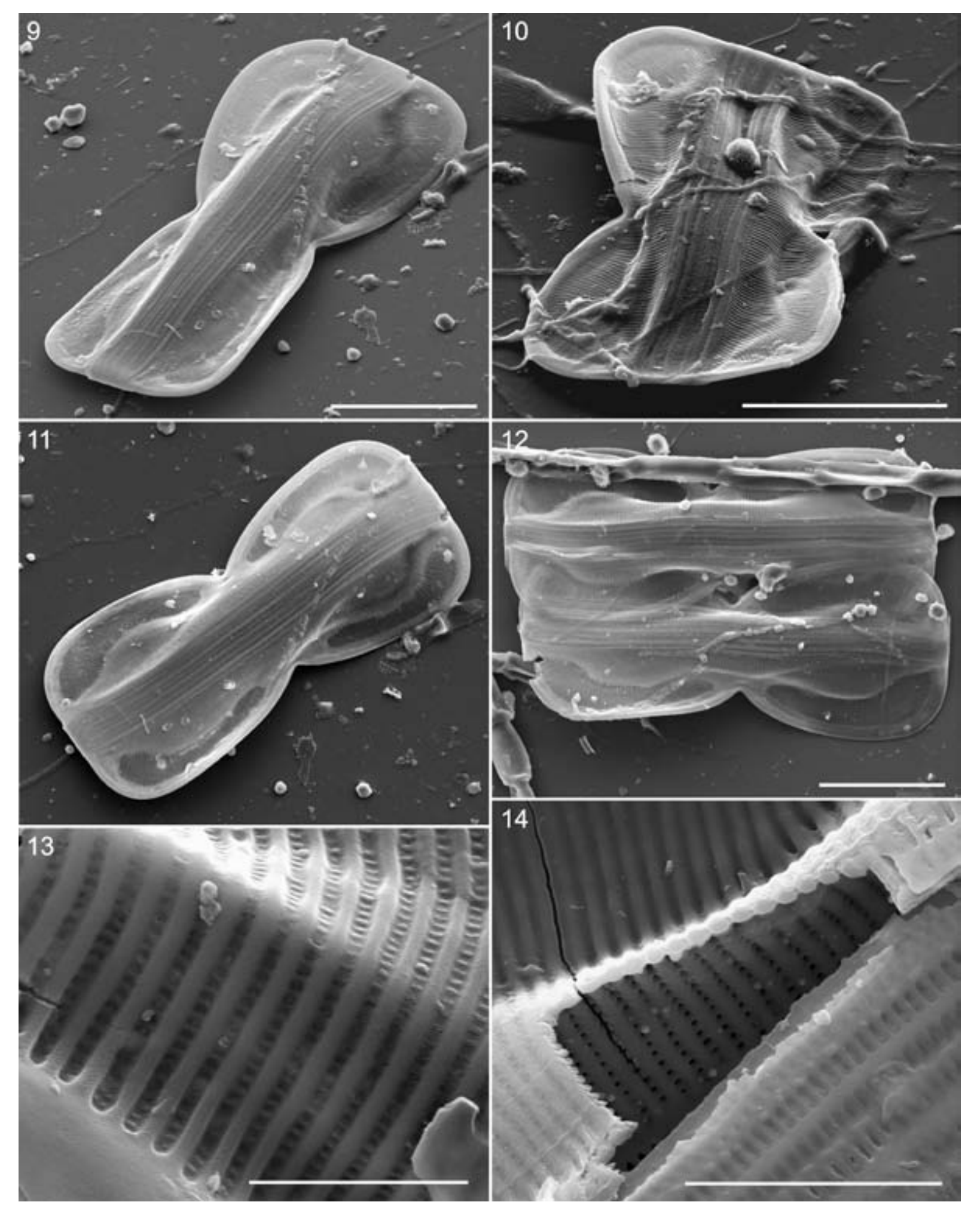

Figs 9-14. SEM showing material on Smith's original mica preparation: (9-12) View of complete valves; (13) Valve exterior near to mantle $\mu \mathrm{m}(13)$ and $5 \mu \mathrm{m}(14)$

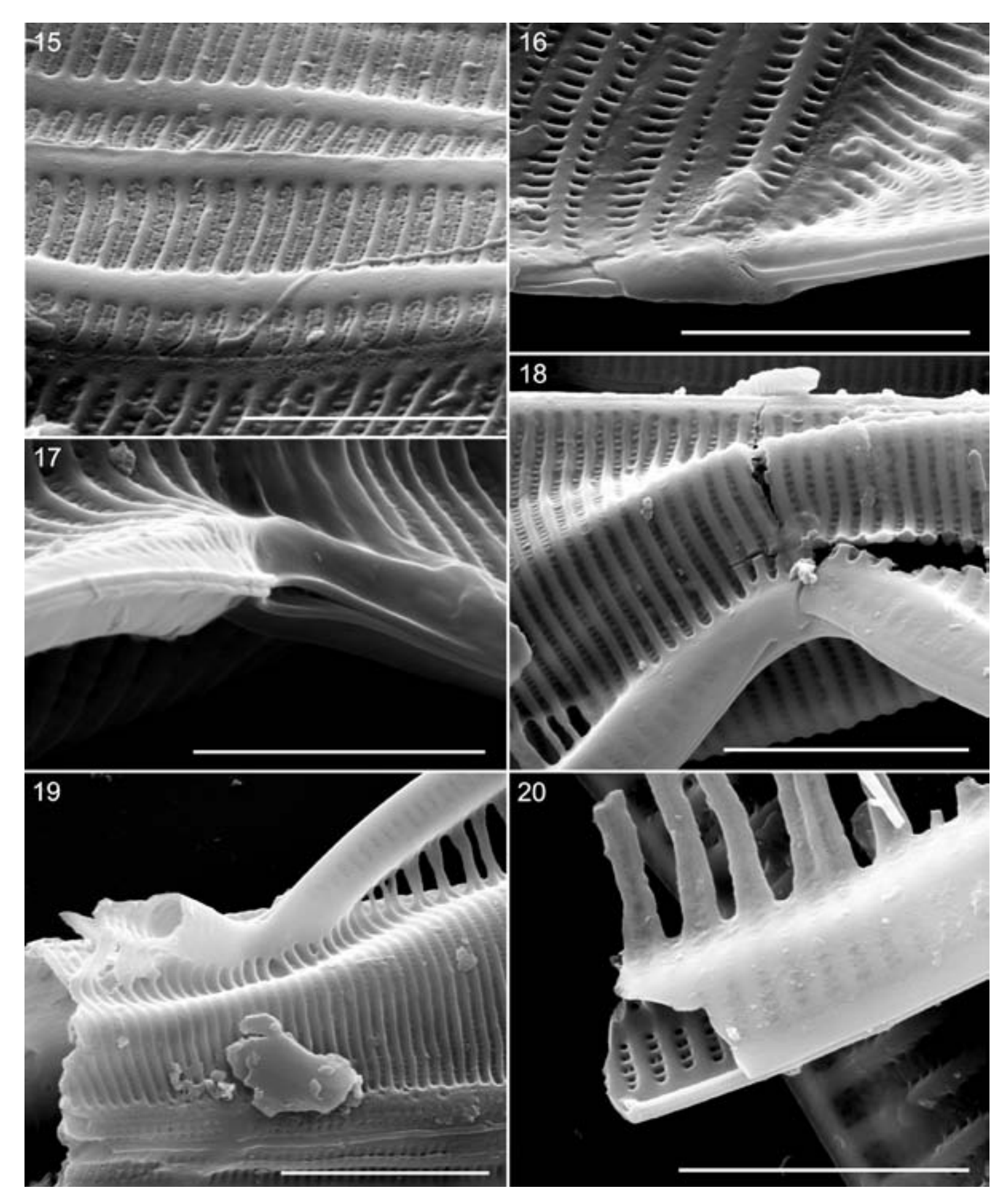

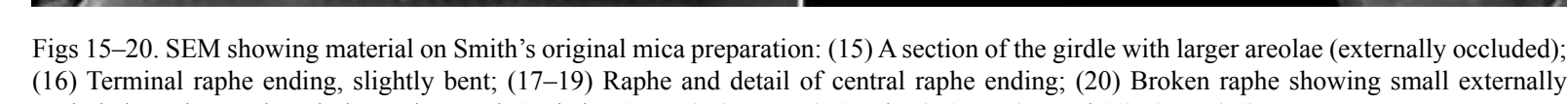
occluded areolae on the tubular raphe canal. Scale bar $2 \mathrm{\mu m}(15), 5 \mathrm{\mu m}(16$ and 19$), 3 \mathrm{um}(17 \mathrm{and} 20), 4 \mathrm{\mu m}(18)$. 

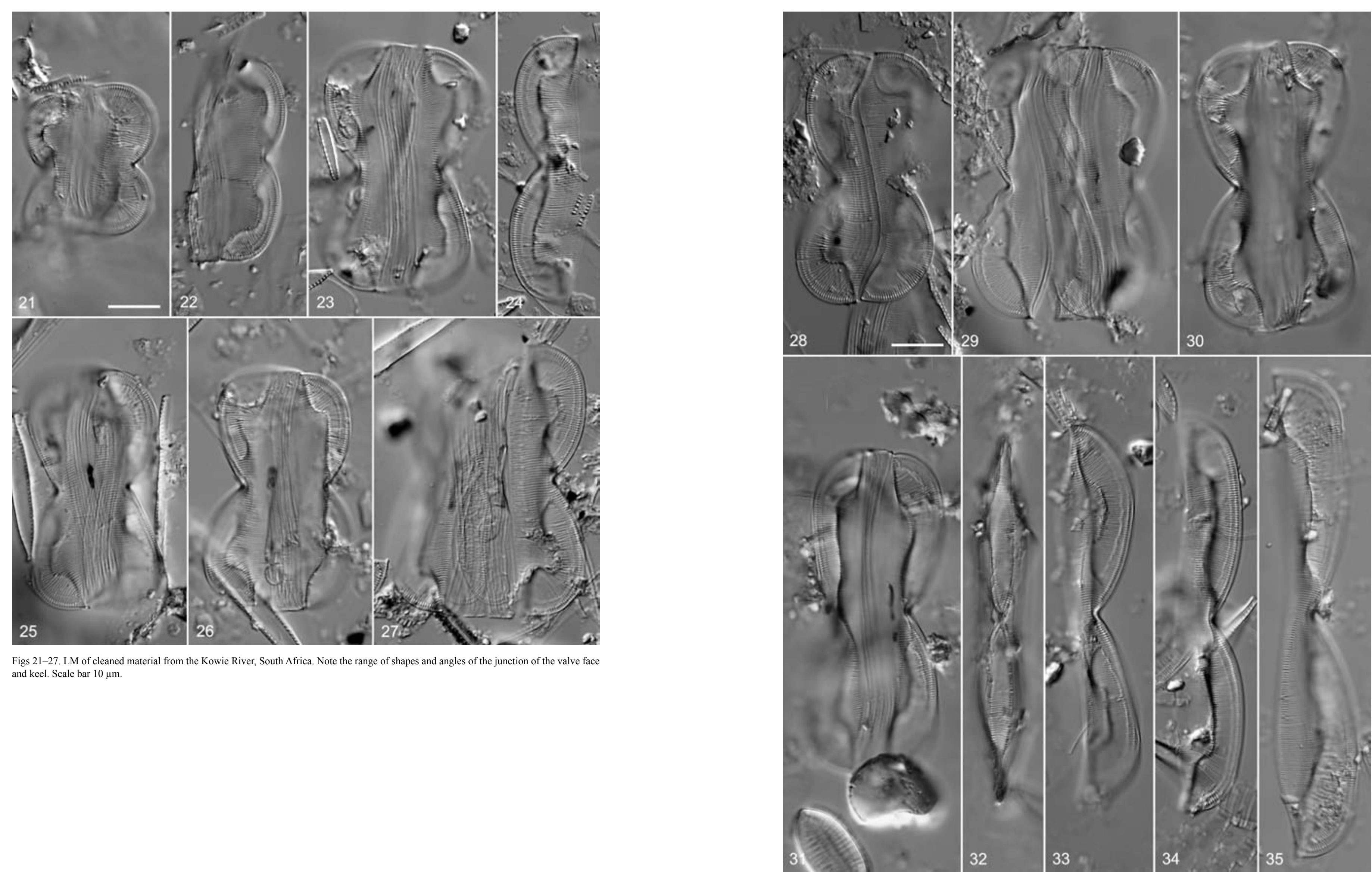

Figs 28-35. LM of cleaned material from the Kowie River, South Africa. Scale bar $10 \mu \mathrm{m}$. 


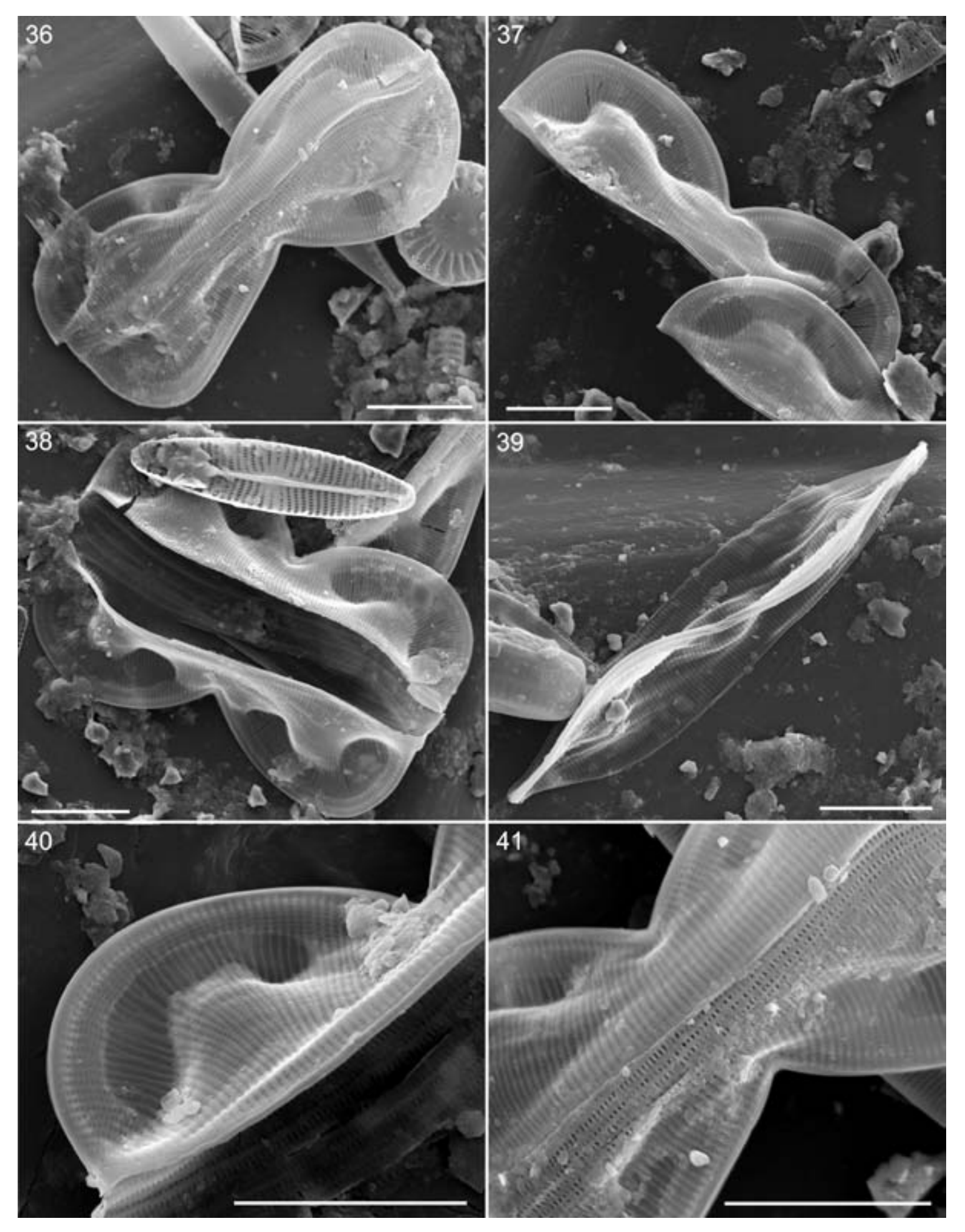

Figs $36-41$. SEM of material from the Kowie Rive,
Girdle region, detail of copulae. Scale bars $10 \mu \mathrm{m}$.

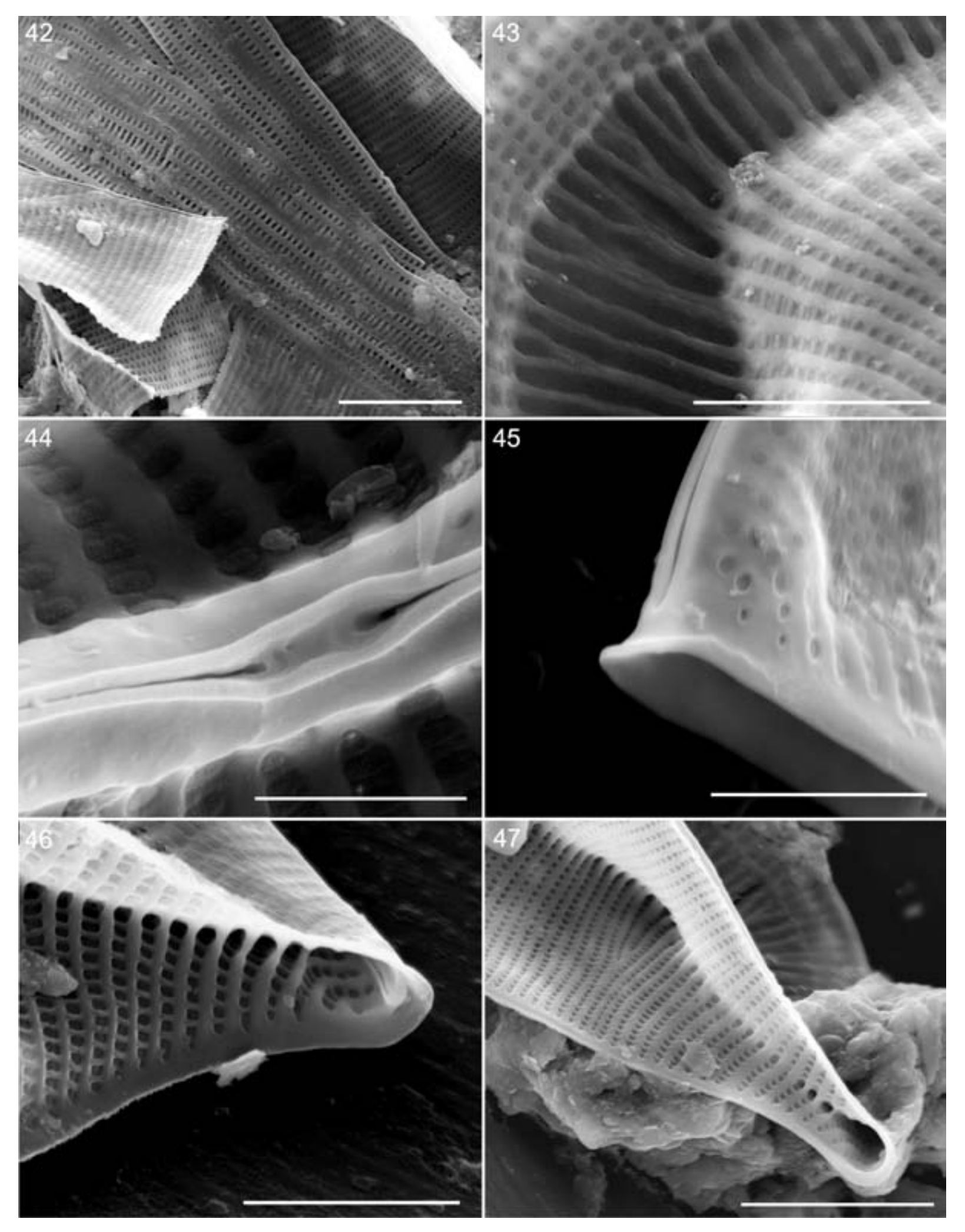

Figs 42-47. SEM of material from the Kowie River, South Africa: (42) Copulae perforated by elongated areolae; (43) Junction of the valve
face and keel, showing externally occluded areolae; (44) Central raphe endings; (45) Terminal raphe ending; (46-47) Internal views showing

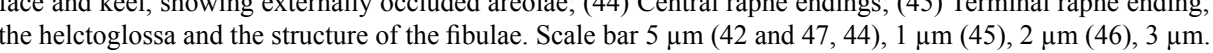




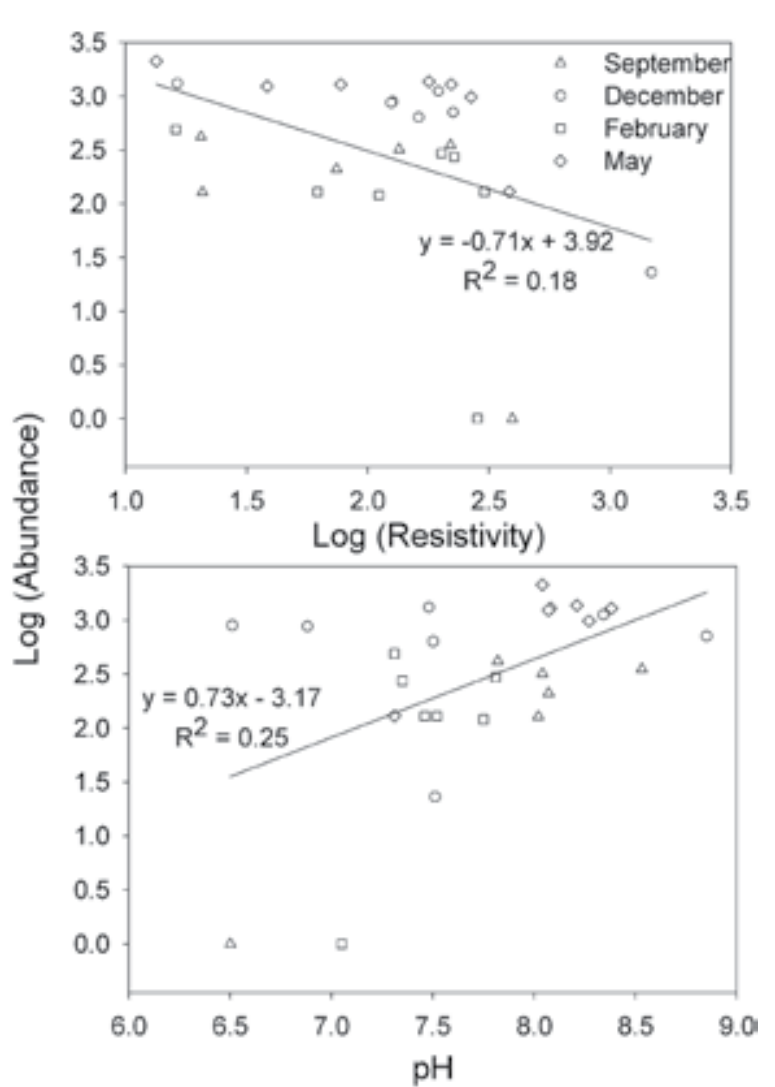

Fig. 48. $\log (\mathrm{x}+1)$ correlation of $E$. puladosa abundances with physico-chemical factors

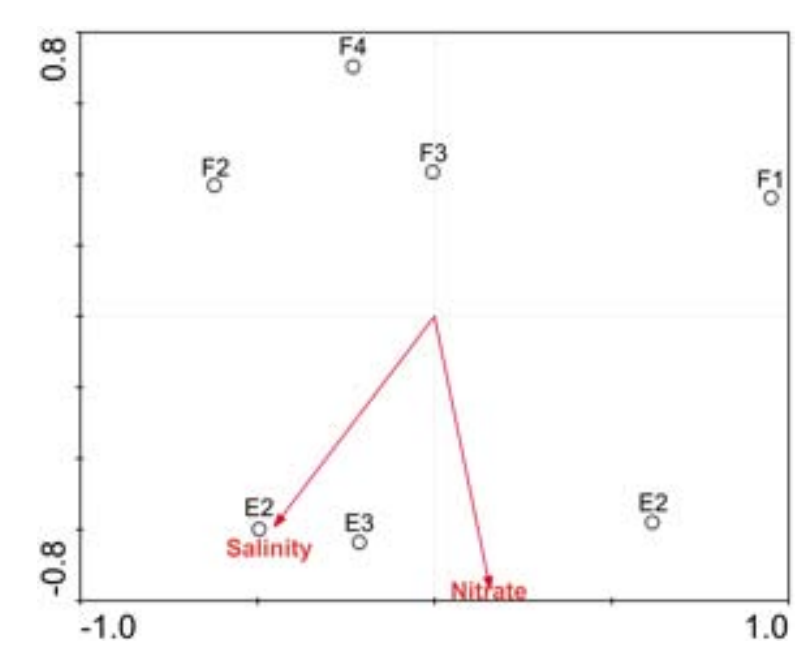

Fig. 49. Redundancy analysis plots showing effects of physicochemical factors on $E$. paludosa taxa samples/sites in the ordination
space of the first and second axes. [(F1-F5), (E1-E3) are the study space of the first and second axes. [(F-
sites where the species were collected]

Сноцкоку, B.J. (1960): The relationship between Algae and the chemistry of natural waters. C.S.A. (Consei Specialist Meeting on Water Treatment. Comission for Technical Co-operation in Africa, South of the Sahara, Pretoria 1960: Publication 64: 215-225.

CноцмокY, В.J. (1962): Beitrage zur Kenntnis der
südafrikanischen Diatomeenflora III. Diatomeenaus der Kaap-Provinz. - Revista de Biologia 3: 1-80. C Q B.N.J. (1966). Dawomeen assoziationen aus einigen Quellen in Südwest-Afrika und
Beih. Nova Hedwigia 21: 163-244.

ChoLnokY, B.J. (1966b): Die Diatomeen im Unterlaufe des Okawango-Flusses. - Beih. Nova Hedwigia 21: 1-102. (1966c): Über die Diatomeen des Stausees einer Goldgrube nahe Welkom in Südafrika. - Revue Algol. n. s., 8: 160-171.

CHoLNoKY, B.J. (1968): Die Diatomeen assoziationen der Santa-Lucia-Laguna in Natal (Südafrika). - Bot.

Cleve-Euler, A. \& Tell, V. (1930): Amphiprora alata (Her.)
Kg. 1844 - Vgl Hustedt in Pascher. F. 1402 a-d. 32

Coste, M. \& RICARD, M. (1982): Contribution a l'étude des diatomées d'eau douce des Seychelles et de l'îl

Dalu, T.; CLEGG, B \& N Nuwatwwalogie 3: 279-313. T.; CLEGG, B. \& NHIWATIWA, T. (2013): Temporal
variation of the plankton communities in a small variation of the plankton communities in a small
tropical reservoir (Malilangwe, Zimbabwe). - Trans Royl Soc S Afr 68: 85-96.

Dalu, T.; Richoux, N.B \& Froneman, P.W. (2014): Phytoplankton community diversity along a riverestuary continuum. - Trans Royl Soc S Afri 69; 107-116.

De Ton, G.B. \& Forti, A. (1913): Contribution à la flore algologique de la Tripolitaine et de la Cyrénaïque.

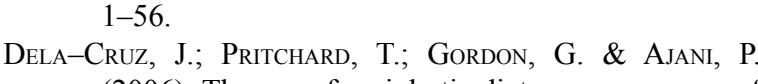
(2006): The use of periphytic diatoms as a means of assessing impacts of point source inorganic nutrien pollution in south
Biol. 51: $951-972$.

Eaton, A.; Clesceri, L.S.; Rice, E.W. \& Greenberg, A.E (2005): Standard for the examination of water an wastewater. $21^{3}$ edition. - American Water Work Association (APHA) and Water Environmen

EHRENBERG, C.G. (1845): Vorläufige zweite Mettheilung über die weitere Erkenntnifs der Beziehungen des kleinsten organischen Lebens zu den vulkanischen Massen
der Erde. - Bericht über die zur Bekanntmachun $\begin{array}{ll}\text { geeigneten } & \text { Verhandlungen der Königlich- } \\ \text { Preussischen Akademie der Wissenschaften z }\end{array}$ Preussischen Akademie der Wissenschaften z Berlin 1845: 133-157,

FoGED, N. (1986): Diatoms in Gambia. - Bibliotheca F. (1986): East African diat

GASSE, F.(1986): East African diatoms. Taxonomy, ecological D. (1954): Recherches phytologica 11: 1-201 Maroc. - Trav. Inst. Sci. Cherifien, Sér. Bot. 4: 1-306.

GIFFen, M.H. (1963): Contributions to the diatom flora of Southern Africa. I. Diatoms of the Estuaries of the Eastern Cape Province. - Hydrobiologia 21: 201-

265.
GIFFen, M.H. (1966): Contributions to the diatom flora of Southern Africa. II. Diatoms from the Hog's Back
Region of the Amatola Mountains, Eastern Cape Province, South Africa. Beih. z - Nova Hedwigi 21: $123-160$. GIFFEN, M.H. (1970): New and Interesting Marine and
Littoral Diatoms from Sea Point, near Cape Town,
South Africa. - Botanica Marina 13: 87-99

GUIRY, M.D. (2013): Entomoneis alata (Ehrenberg) Ehrenberg, 1845. - In: GUIRY, M.D. \& GuIRY, G.M. (eds): AlgaeBase. World-wide electronic
publication. - National University of Ireland Galway (taxonomic information republished from AlgaeBase with permission of M.D. Guiry). Accessed through: World Register of Marine Species at http://www.marinespecies.org/aphia php?p=taxdetails\&id $=157428$ on $2013-09-27$. Accessed 27 September 2013

Heydorn, A.E.F. \& GrindLEY, J.R. (1982): Estuaries of the Cape. Part II: Synopsis of available information on individual systems. - In: Report No.1 Kowie (CSE
10). CSIR Research Report 409. - National Research Institute for Oceanology. Creda Press, Cape Town.

HustedT, F. (1930). Bacillariophyta (Diatomae). - In: Pascher, A. (ed.): Die Süsswasser-Flora Mitteleuropas, part 10. -466 pp., Jena, G. Fischer.

LepŚ, J. \& SMILAUER, P. (2003): Multivariate analysis of ecological data using CANOCO. - $269 \mathrm{pp}$. ity Press, New York

Јов, H.S. (1954): List of Diatoms found in neighbourhood of

Alexandria, Egypt. - pp. 1-9, Private Print.
Krammer, K. \& Lange-Bertalot, H. (1986): Bacillariophyceae. 1. Teil: Naviculaceae. - In: ETTL,
H.; GERLOFF J.; HeYNIG, H. \& MolLenHAUER, D. (eds) Susswasserffora von Mitteleuropa, Band 2/1. - 876

pp., Gustav Fisher Verlag, Jena.
Kent, L.E. \& Rogers, A.W. (1947): Diatomaceous deposits in the Union of South Africa : with special reference to Kieselguhr. Memoir (Geological Survey of
Africa), no. 42, - Government Printer, Pretoria.

LeuduGer-Fortmorel, G.M.D. (1898): Diatomées marines de la Côte occidentale d'Afrique. - Saint-Brieuc. $1-41$.

Masson, H. \& MaraIS, J.F.K. (1975): Stomach conten analyses of mullet from the Swartkops estuary. ZW. (1932): Some ditoms fion

MLLL, F.W. (1932). Some diatoms from Warri, South Nigeria . . Royl. Microscopy Soc. 52: 383-394.

Patrick, R.M. \& Reimer, C.W. (1975): The diatoms of the United States, exclusive of Alaska and Hawaii. Vol 2. - In: Monographs of the Academy of Natura
Sciences of Philadelphia 13. - 113 pp., Academy of

Natural Sciences, Philadelphia.
Ros, M.D.; MARín-MurciA, J.P. \& ABOAL, M. (2009): Biodiversity of diatom assemblages in a Mediterranean semiarid stream. implications for CR, VM. in GUIRY, M.D \& GUTPY, GM. (2014):

SALVADOR, V.M. in GUIRY, M.D. AlgaeBase. - World-wide electronic publication, algaebase.org; Retrieved 4 Aprii 2014

ScotT, F.J. \& THомAs, D.P. (2005): Diatoms. - In: Scoтt, F.J \& MARCHANT, H.J. (eds): Antarctic marine protists. pp. 13-201, Canberra \& Hobart: Australian Biological Resources Study; Australian Antarctic Division.

Senyatso, K.J.; Collar, N.J., \& Dolman, P.M. (2013) Assessing range-wide conservation status change in an unmonitored widespread A
Diversity Distrib 19: 106-119.

SIIVA, E.S. (1956). Conthibution à letude du microplancton de Dakar et des regions maritimes voisines. - Bull.
Inst. franc. Afr. noire, Ser. A, 18: 335-371. W. (1853): Synopsis of British Diatomaceae. -89 pp. pls 1-31, John Van Voorst, London,

(2.7). STSS Relcase 16.0.0 for Windows. - Pola Engineering and Consulting. Chicago, SPSS Inc. Recommendations for the collection, preparation and enumeration of diatoms from riverine habitats for water quality monitoring in South Africa. - Afri. J. Aquat. Sci. 30: 65-75,

TAYLOR, F. J. (1966): Phytoplankton in the Sierra Leone Rive - Journal of the West African Science Association 11

Rr BraAK, C.J.F. (2002): Canoco version 4.5. Biometrics quantitative methods in the life and earth sciences. and Research Centre, Wageningen.

WAwRIK, F. (1984): Notizen zur Algenflora von Tunisie und der Südküste Islands. - Limologica (Berlin) 16

181-184.
WECKSTRŌM, K. \& JUGGiNs, S. (2005). Coastal diatomenvironment relationships from the Gulf of Finlan

Whitfeld, A.K.; PAterson, A.W.; BoK, A.H. \& KoK, H.M. permanently open Eastern Cape estuaries. - Sth. Afri. J. Zoo. 29: 175-186.

Wood, E. J. F. (1965): Protoplankton of the Benguela-Guine current region. - Bulletin of Marine Science of the Gulf and Caribbean 15. 475-479.

Woobs Sula Leene. I. New and unusual Algae from the

WoodHeAd, N. \& TwEed, R.D. (1960): A second check-list of tropical West African algae. - Hydrobiologia 15 $225-286$

\section{Czech Phycological Society (2015)}

Accepted November 14, 2014 